\title{
The language aspects of children with high abilities/giftedness: an integrative literature review
}

Pontifícia Universidade Católica de Minas Gerais - PUC/MG, Belo Horizonte, Minas Gerais, Brasil.

Conflict of interests: Nonexistent

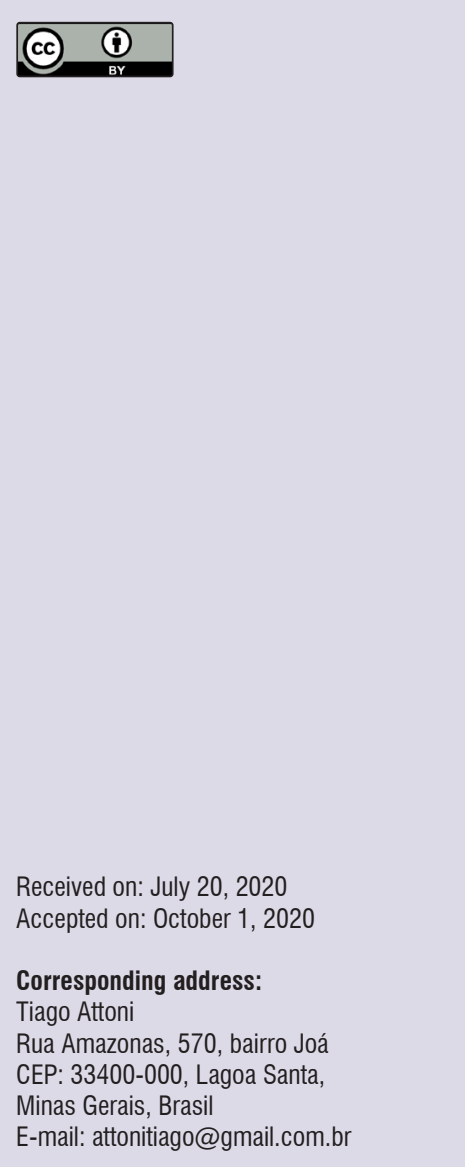

Tiago Attoni ${ }^{1}$

https://orcid.org/0000-0001-9832-7965

Rebeca Coelho ${ }^{1}$

https://orcid.org/0000-0002-6321-4757

Rafaela Martins ${ }^{1}$

https://orcid.org/0000-0002-5435-8716

Laura Lemos ${ }^{1}$

https://orcid.org/0000-0003-4018-5292

Laura Fernandes ${ }^{1}$

https://orcid.org/0000-0001-8375-4630

Thamyris Francis ${ }^{1}$

https://orcid.org/0000-0001-7943-6859

Sara Fernandes ${ }^{1}$ https://orcid.org/0000-0001-8033-960X

Karina Fideles ${ }^{1}$

https://orcid.org/0000-0003-3212-537X

\section{ABSTRACT}

Purpose: to analyze information and characteristics of the language of children diagnosed with high abilities and giftedness.

Methods: an integrative literature review based on a search in LILACS, MEDLINE, and Google Scholar databases, combining the keywords "Speech-Language-Hearing and high abilities", "giftedness and child language".

Results: a total of 45 articles that met the inclusion criteria were analyzed, of which 29 were excluded and 16 selected for the review. The analysis of these articles made it possible to verify, though superficially, the aspects in the oral and written language of children with high abilities and giftedness. These children's vocabulary and discourse are usually rich, with excellent comprehension skills. There is early interest in reading, besides noteworthy writing comprehension and decoding skills. The studies indicate that these capacities are atypical when compared with those of the population referred to as normal. The discourse of gifted children tends to be compatible with that of children two years older, and their language develops faster.

Conclusion: the language of children diagnosed with high abilities and giftedness has particularities that must be better studied, as their development differs from that of other children.

Keywords: Speech, Language and Hearing Sciences; Child Rearing; Child, Gifted; Child Language 


\section{INTRODUCTION}

The terms used to define people whose potential goes beyond average appeared in the Brazilian context circa 1929. They were first named super-normal, then gifted, exceptional, highly gifted, and, currently, people with high abilities and/or giftedness. The first official use of the term "highly gifted" was in 1971, in the Law on Guidelines and Bases for Education 5,692/71, in article 9, which stated that the highly gifted students should receive special treatment, following the norms established by the responsible Education Councils. However, as Brazil advanced in terms of inclusive education, the term "high abilities" appeared in 1994, when the National Special Education Policies were published ${ }^{1,2}$.

People diagnosed with high abilities/giftedness $(\mathrm{HA} / \mathrm{G})$ can learn very easily, mastering concepts, procedures, and attitudes with quick clarity. As a consequence, they can both deepen and enrich the content they acquire ${ }^{2-4}$

The regulatory law on the National Special Education Policies in the Perspective of Inclusive Education clarifies that students with $H A / G$ have an elevated potential in any of the following areas, either alone or in combination: intellectual, academic, leadership, psychomotricity, and arts, besides having great creativity and commitment to learn and perform tasks in their fields of interest ${ }^{3,4}$.

Nevertheless, people with $\mathrm{HA} / \mathrm{G}$ make up a quite misunderstood and often neglected group. Hence, the scenario is that of professionals incapable of actually comprehending the truths and myths involved; consequently, they fail to assist these people. An important aspect to realize is that children are rarely highly gifted in all academic domains. They can have a great performance in a given field or subject and still have clearly noticed difficulties in other segments. Some people with HA/G can have good school achievements, while others can have low performance and need specialized help ${ }^{4-7}$.

Research carried out on this theme have pointed to the need for specialized attention to people with $\mathrm{HA} / \mathrm{G}$ as early as possible, encompassing actions within the educational institutions throughout basic education, as this is considered the ideal place and time to develop their potentials ${ }^{4}$. This shows the importance of understanding these peoples' language development, especially as it is not a homogeneous group, whose abilities are developed within specific needs and situations.
In consonance with the abovementioned information, it is highly important to identify studies that clearly and objectively indicate the language characteristics of people with $\mathrm{HA} / \mathrm{G}$, as it is still a quite unexplored theme, particularly regarding SpeechLanguage-Hearing Sciences. Thus, this study aimed to analyze the information and characteristics of children diagnosed with high abilities/giftedness.

\section{METHODS}

This integrative review of the literature sought to analyze the main articles that refer to the proposed theme. The main access theme was: Language of children with high abilities/giftedness.

The stages in this review encompassed defining the theme and research problem, developing clear objectives, choosing descriptors, selecting inclusion and exclusion criteria, analyzing the knowledge already produced, categorizing the data, and presenting the results.

The search for articles took place between February and June 2020. The data was obtained with a bibliographic survey conducted in LILACS (Latin American and Caribbean Health Sciences Literature), MEDLINE (Medical Literature Analysis and Retrieval System), and Google Scholar databases.

The inclusion criteria for reading the abstracts and articles in full were defined as: a) studies with humans whose sample was of children and adolescents (under 18 years old); b) studies whose subjects had been diagnosed with $\mathrm{HA} / \mathrm{G}$; c) the presence of dyslexia and autism as comorbidities; d) publications from as far back as 2000; e) publications in Portuguese, English, or Spanish; f) studies designed as case series, longitudinal, cross-sectional, case-control, cohort, and clinical trials.

For the exclusion of articles, the following criteria were used: a) studies with an adult or older adult sample (over 18 years old); b) children or adolescents without a definite diagnosis of $\mathrm{HA} / \mathrm{G}$; $\mathrm{c}$ ) studies not centered on $\mathrm{HA} / \mathrm{G}$; d) papers unrelated to the concept of language in $\mathrm{HA} / \mathrm{G}$, either in their oral or written manifestation.

Altogether, 519 articles were found. According to the inclusion and exclusion criteria, various articles were dismissed as they had the following characteristics: sample over 18 years old (four); without a definite diagnosis (six); other central themes (382); language was not approached as a theme (108).

Each of the 45 remaining articles was minutely read, emphasizing those that met the objectives proposed in 
this study, to organize the data. Following the inclusion criteria, 16 studies were selected for analysis, and are referred to in the present text.

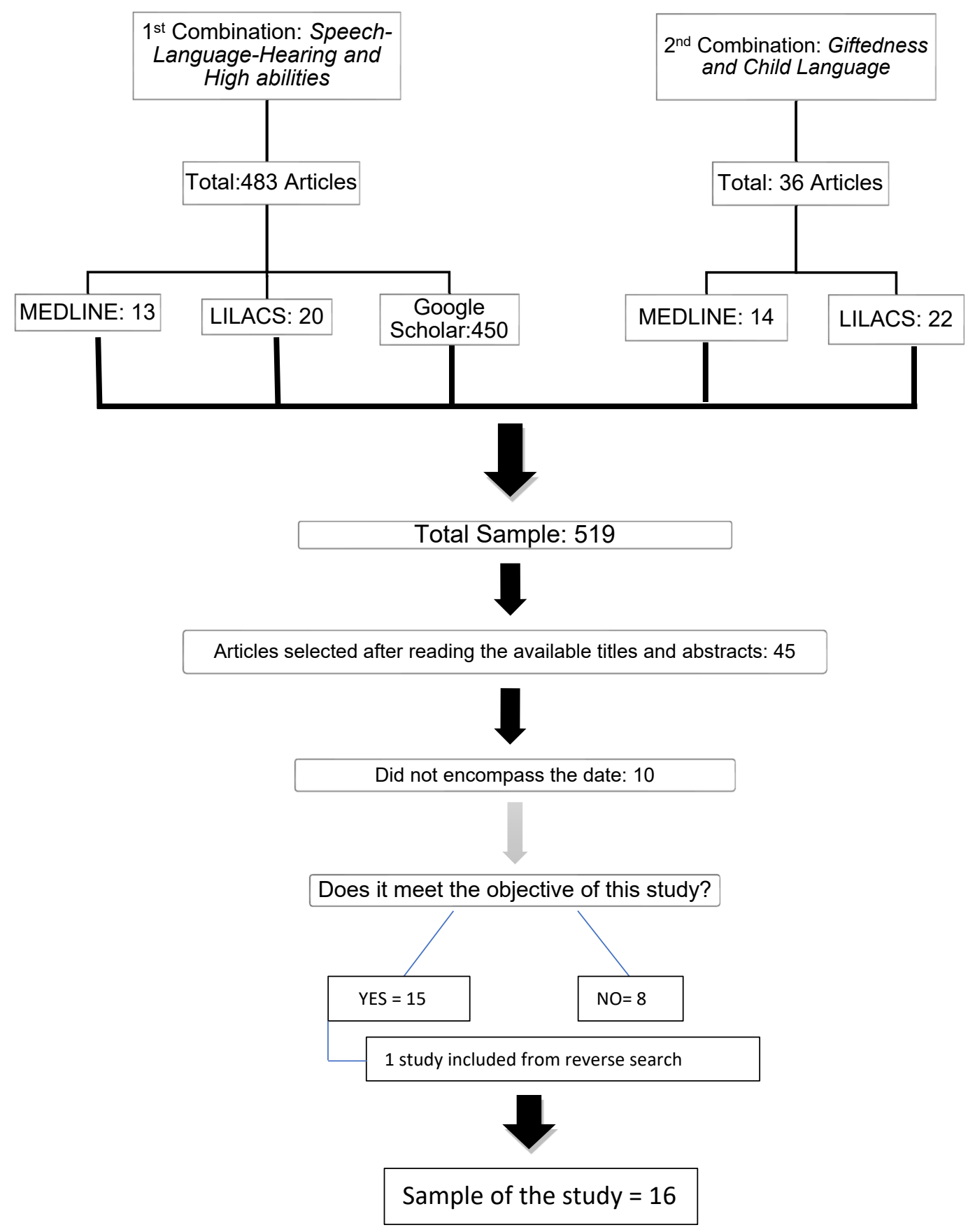

The flowchart detailing the process of screening and selecting the articles can be verified in Figure 1.

Figure 1. Demonstrative flowchart of the bibliographic survey 


\section{LITERATURE REVIEW}

The results of the bibliographical survey on this theme indicate that there is a limited proportion of articles in the scientific literature. This was beyond any doubt the greatest obstacle to structure this paper.

The electronic search resulted in 519 articles, which were submitted to evaluation to verify the possibility of being included in the present review. Following the predefined inclusion and exclusion criteria, 16 articles met the proposal of this study.

After the exploratory analysis of the themes in the articles, they were divided into two groups: 1) oral language; 2) written language.

\section{Oral language}

The children with $H A / G$ tend to present excellent percentages in tasks that assess oral language skills particularly vocabulary, which is broad for these subjects' age ${ }^{8}$.

Corroborating this statement, a study investigated the narrative capacity of children with $\mathrm{HA} / \mathrm{G}$ in comparison with a control group of children of the same chronological age. The highly gifted children organized their discourses in a way typical of children two years older. The basic-structure constructions were richer and more sophisticated, with more developed stories than those of their mates in the same chronological age. The highly gifted children also showed considerable advancement in various language skills ${ }^{9}$.

These children have a high cognitive skill regarding comprehension; they can concentrate and remain attentive for longer; they are intrinsically motivated to learn and explore; they are persistent. Moreover, they are highly capable of observing and paying attention to details; they are independent; they have well-developed abstraction, conceptualization, and synthesis skills; they quickly perceive similarities, differences, and anomalies ${ }^{9,10}$.

Highly gifted children are able not only to develop language faster than the other children but also to develop different ways of thinking. Theories indicate that there is a great motivational effort, without needing external stimuli, highly capable of administrating their learning of new concepts ${ }^{10-12}$.

However, extremely high capacity in one area may coexist with a common or even abnormal capacity in another area. These children are frequently irregular; for instance, the mathematical skills may be much higher than the verbal capacity, with brief phonological occurrences and short, extremely objective discourses. In other cases, the child can be intensely communicative, with rich expressions in their vocabulary, excellent linguistic mastery, easily learning a second language - while their limitation and uninterest are clearly noticed in other fields of knowledge ${ }^{10}$.

Autism Spectrum Disorder is known to be associated with $\mathrm{HA} / \mathrm{G}^{11-14}$. In a study conducted in Rome, a nine-year-old child diagnosed with autism spectrum disorder and HA/G had the linguistic aspects of their speech assessed. The researchers identified in that study different levels of metalinguistic awareness. The child achieved a low level in the semantic assessment, whereas the response in phonology and grammar was good. According to the authors, when the child had to solve linguistic problems, such as grammar and phonology, they apparently behaved as if they were dealing with questions, imposing predefined correspondences between form and meaning. When they had to deal with semantic issues, the child seemed to lose control over the meanings, and their responses were worse. The same authors called attention to the need to investigate the pragmatic aspect of language in these subjects - an important intersection between language and social cognition ${ }^{11}$.

\section{Written language}

Before referring to the written language development in children with $\mathrm{HA} / \mathrm{G}$, it is important to highlight that they are included in the National Special Education Policies in the Perspective of Inclusive Education, secured by the National Guidelines for Special Education in Basic Education, Resolution no. 02, of September 11, 20012,3.

In this perspective, the inclusion process of children with $\mathrm{HA} / \mathrm{G}$ must encompass the training of teachers to identify possible indicators of such a condition. The child neurodevelopmental stages must be under the control of the education professional, for them to identify different behaviors and actions that indicate high abilities ${ }^{5}$.

Students with $H A / G$ are different from those referred to as normal, i.e., the majority of them. Therefore, they need adequate technical support, and it is the educator's responsibility to recognize and work on these differences ${ }^{3,5,7}$.

A program was applied in the United States from 1977 to 1988 to enrich the teachers' training and potentialize the inclusion process of children with $\mathrm{HA} / \mathrm{G}$. The proposals: 
- I: consisted of exposing the students to subjects, people, places, and situations different from those in the regular curriculum. To carry out this process, it was necessary to count on a team made up of parents, teachers, and students that approached the new knowledge with lectures, workshops, movies, and so forth.

- II: consisted of using materials and methods to develop cognitive and affective skills. It had two stages: the first took place in the classroom, where the child was exposed to situations that required creative thinking and problem-solving; specific skills to use advanced materials; visual, oral, and written communication skills; and development of the affective process. The second stage consisted of methodological teaching related to specific subjects of interest developed by the student in enrichment type I.

- III: involved students that were interested in an in-depth approach of the subject chosen through research, taking on the role of researchers. The objectives of this enrichment process consisted in the acquisition of an advanced level of comprehension of knowledge (content) and methodology (process); opportunity to relate interests, knowledge, and ideas; development of the organization, planning, time administration, decision-making, and self-assessment skills; acquisition of self-confidence; development of feelings of creative achievement ${ }^{5}$.

The school needs to perceive and identify the needs of gifted students in basic education. This process will only take place if the teacher pays close attention to the children's development stages and their participation in the construction of knowledge as proposed ${ }^{5}$. Some students with $\mathrm{HA} / \mathrm{G}$ can indeed have a good school performance, whereas others, equally with $H A / G$, have low school achievement. These need specialized attention, as they frequently tend to manifest a lack of interest and motivation for academic studies and school routine ${ }^{15}$.

The children with $H A / G$ begin to read quite early, possibly before they enter the basic school system. They usually present an advanced level of reading comprehension and decoding skills, besides a broad interest in linguistic aspects. When the subjects get them interested, their curiosity is enhanced, leading them to easily assimilate the content ${ }^{16}$.

Surprisingly, Viersen et al. $(2016)^{8}$ identified in their study that children diagnosed with $H A / G$ and dyslexia can disguise literacy problems using possible compensatory mechanisms. The sample comprised 121 Dutch primary schoolchildren divided into four groups: 1) children in typical development; 2) children with dyslexia; 3) children with HA/G; 4) children with both $\mathrm{HA} / \mathrm{G}$ and dyslexia. The children were submitted to a battery of tests that included literacy measures (reading/orthography) and cognitive skills related to literacy and language: phonological awareness, rapid automatic naming, short-term verbal memory, working memory, grammar, and vocabulary. The result identified that these subjects present response rates similar to those of subjects with typical development, in all cognitive skills tested. However, regarding phonological awareness, clear signs of difficulty were found. This indicates that phonology is a risk factor for children with $\mathrm{HA} / \mathrm{G}$ and dyslexia, which on the other hand is moderated by other skills, such as working memory, grammar, and vocabulary. These provide opportunities to compensate for a cognitive deficit and disguise the literacy difficulties.

\section{CONCLUSION}

This review identified that there are specific language aspects in children diagnosed with $\mathrm{HA} / \mathrm{G}$, which become clear when the oral and written language are observed. The children with $\mathrm{HA} / \mathrm{G}$ seem to use language in an atypical way. These subjects have elevated potentials in most of the linguistic skills - which, on the other hand, may coexist with a deficiency in some language component, either oral or written, disguising possible difficulties. Knowledge of these particularities can help create strategies for their best achievements in social and learning settings. Lastly, there is a clear scarcity of studies assessing these subjects' language, particularly with a speech-language-hearing approach.

\section{REFERENCES}

1. Branco APSC. Breve história acerca das altas habilidades/superdotação: políticas e instrumentos para a identificação. Educação, Batatais. 2017;7(2):23-41.

2. Souza VS. Altas habilidades e superdotação: uma reflexão sobre o tema [Monografia]. Medianeira (PR): Universidade Tecnológica Federal do Paraná, Curso de Pós-graduaçao em Educação: Métodos de Técnicas de Ensino; 2013. 
3. BRASIL. SECRETARIA DE EDUCAÇÃO. MINISTÉRIO DA EDUCAÇÃO. Projeto Escola Viva: alunos com necessidades especiais educacionais especiais. Série 2. Brasília: Ministério da Educação, Secretaria de Educação Especial. 2002. http:// portal.mec.gov.br/seesp/arquivos/pdf/construindo. pdf.

4. Cardoso AOG, Becker MAD. Identificando adolescentes em situação de rua com potencial para altas habilidades/superdotação. Rev. Bras. Educ. Esp. 2014;20(4):605-14.

5. Mettrau MB, Reis HMMS. Políticas públicas: altas habilidades/ superdotação e a literatura especializada no contexto da educação especial/inclusiva. Ensaio: aval.pol.públ.Educ. 2007;15(57):489-509.

6. Pérez SGB, Freitas SN. A Mulher com altas habilidades/superdotação: à procura de uma identidade. Rev. Bras. Educ. Esp. 2012;8(4):677-94.

7. Martins BA, Chancon MCM. Crianças precoces com indicadores de altas habilidades/superdotação: as características que contrariam a imagem de aluno “ideal”. Educação Unisinos. 2016;20(1):96-105.

8. Viersen SV, Evelyn H, Kroesbergen EH, Slot EM, Bree $\mathrm{EH}$. High reading skills mask dyslexia in gifted children.J Learn Disabil. 2016;49(2):189-99.

9. Porath M. Narrative performance in verbally gifted children. $J$ for the Educ of the Gifted. 1996;19(3):276-92.

10. Winner E. Giftedness: current theory and research. Amer Psych Soc. 2000;9(5):153-6.

11. Melogno S, Pinto MA, Levi G. Profile of the linguistic and metalinguistic abilities of a gifted child with autism spectrum disorder: a case study. Child Lang Teach Ther. 2015;31(1):113-26.

12. American Psychiatric Association (2013) Diagnostic and statistical manual of mental disorders. 5th edition. Arlington, VA: American Psychiatric Publishing.

13. Melogno S, Pinto MA, Levi G. Metaphor and metonymy in ASD children: a critical review from a developmental perspective. Res. Autism Spectr. Disord. 2012;6(4):1289-96.

14. Assouline SG, Foley Nicpon M, Dockery L. Predicting the academic achievement of gifted students with autism spectrum disorder. J Autism Dev Disord. 2012;42(9):1781-9.
15. Francis R, Hawes DJ, Abbott M. Intellectual giftedness and psychopathology in children and adolescents. Exceptional Children. 2015;82(3):279-302.

16. Gokaydin B, Baglama B, Uzunboylu H. Language learning of gifted individuals: a content analysis study. Teach. Prof. Dev. 2017;19(1):109-18. 